\title{
Discovery of Thiopyrimidinone Derivatives as a New Class of Human Aldose Reductase Inhibitors
}

\author{
Ilária M. S. Lins, ${ }^{\circledR a}$ Larissa G. Maciel ${ }^{\circledR *, a}$ and Janaína V. dos Anjos ${ }^{\circledR *, a}$ \\ ${ }^{a}$ Departamento de Química Fundamental, Universidade Federal de Pernambuco, \\ Av. Jornalista Aníbal Fernandes, s/n, Cidade Universitária, 50740-560 Recife-PE, Brazil
}

\begin{abstract}
Diabetes is a chronic metabolic disorder characterized by insufficient insulin production, the cells' inability to use this insulin, or a combination of both, leading to secondary complications such as diabetic neuropathy and retinopathy. One way to prevent or control such complications is the use of aldose reductase (AR) inhibitors. In this work, we synthesized and tested new candidates for human AR inhibition containing a 2-thiopyrimidin-4-one heterocycle as a central ring. The fifteen derivatives were tested in vitro and their binding modes were evaluated via molecular docking simulations. AR inhibition assays showed that all synthesized compounds were able to inhibit the AR enzyme at $50 \mu \mathrm{M}$. From these results, seven compounds were noteworthy and had their half maximal inhibitory concentration $\left(\mathrm{IC}_{50}\right.$ ) values estimated, ranging from 2.0 to $14.5 \mu \mathrm{M}$. Molecular docking simulations showed that these compounds bind specifically to the catalytic subpocket and the results indicate a good association between in vitro and in silico studies.
\end{abstract}

Keywords: drug discovery, synthetic chemistry, bioorganic chemistry, enzymology, computational chemistry, molecular modelling

\section{Introduction}

Aldose reductase (AR) (EC 1.1.1.21) is a ubiquitous aldo-keto reductase, ${ }^{1-3}$ whose primary function is to catalyze the reduction of toxic aldehydes produced by reactive oxygen species into non-reactive alcohols. ${ }^{3}$ AR activity in hyperglycemic patients is frequently associated with diabetes complications. ${ }^{1-3}$

In order to perform its enzymatic activity, AR uses nicotinamide adenine dinucleotide phosphate (NADPH) as a cofactor in high demand. This overuse results in a low availability of NADPH for other enzymes, such as glutathione reductase (GR), which, in turn, may result in cellular oxidative stress. ${ }^{1-3}$ Another feature related to an AR increased activity is linked to sorbitol, the main AR reaction product. As any highly hydrophilic substance, sorbitol does not diffuse rapidly through cell membranes and can be accumulated in tissues, causing ionic imbalance and cellular osmotic stress. ${ }^{1,2}$ Sorbitol accumulation results in retinopathy, neuropathy and nephropathy; conditions that are closely associated with diabetes. $^{2}$

*e-mail: larissa.gmaciel@ufpe.br; janaina.anjos@ufpe.br

Editor handled this article: Teodoro S. Kaufman
Diabetic retinopathy is one of the most common microvascular complications in this scenario, it can lead to cases of vision loss in adults ${ }^{2}$ and affects almost 3 million people a year. ${ }^{4}$ In addition to controlling blood glucose, treatment for diabetic retinopathy may be complemented with drugs such as acetylsalicylic acid, ${ }^{5}$ vitamin $\mathrm{E},{ }^{6}$ angiotensin-converting enzyme inhibitors (ACE), ${ }^{7}$ vascular endothelial growth factor (VEGF) receptor inhibitors, ${ }^{8}$ and, of course, AR inhibitors. ${ }^{2}$

AR inhibitors present a wide structural diversity, bearing carboxylic acid moieties, cyclic imides, esters derivatives, and heterocyclic derivatives. ${ }^{2}$ Among these, heterocyclic systems containing a carbonyl portion as part of the scaffold appear to be the most promising drug candidates ${ }^{9-11}$ (Figure 1). As stated before, AR is a pervasive enzyme and some problems concerning the use of its inhibitors consist of undesirable effects that include increased levels of liver enzymes and gastrointestinal events, such as nausea and vomiting. ${ }^{12}$ For this reason, there is an unceasing demand for more potent and selective inhibitors for diabetic retinopathy treatment.

Pyrimidines and their oxo-derivatives are widely reported due to their many biological activities, such as antiviral, ${ }^{13}$ antimicrobial,,${ }^{14,15}$ anti-inflammatory, ${ }^{16}$ antioxidant,${ }^{14}$ anticancer agent, ${ }^{17}$ and AR inhibition. ${ }^{10,18}$ 


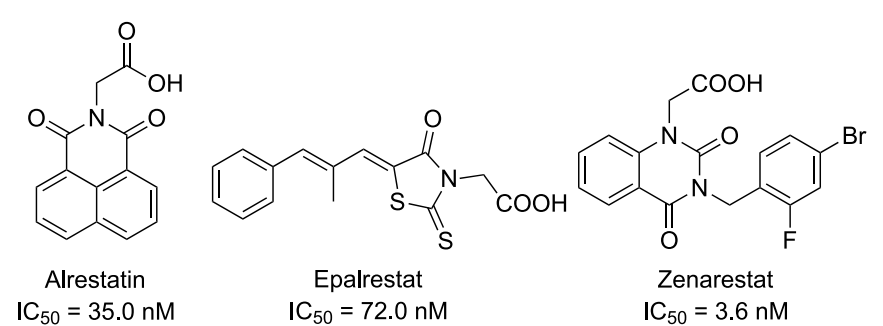<smiles></smiles><smiles>O=C(O)CCCc1nc(-c2cccc([N+](=O)[O-])c2)no1</smiles>

[4-(3-Nitrophenyl)-1,2,4-oxadiazol-5-yl]

Quercitrin

$\mathrm{IC}_{50}=5.0 \mu \mathrm{M}$

butanoic acid

$\mathrm{IC}_{50}=2.4 \mu \mathrm{M}$

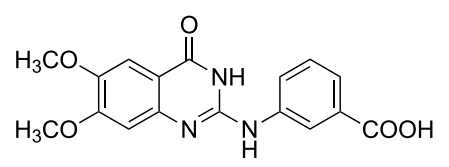

3-(6,7-dimethoxy-4-oxo-3,4-

dihydroquinazolin-2-ylamino)benzoic acid $\mathrm{IC}_{50}=34.0 \mu \mathrm{M}$

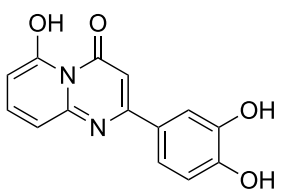

2-(3,4-dihydroxyphenyl)-6-hydroxy4Hpyrido[1,2-a]pyrimidin-4-one $\mathrm{IC}_{50}=0.10 \mu \mathrm{M}$

Figure 1. AR inhibitors and their respective half maximal inhibitory concentration $\left(\mathrm{IC}_{50}\right)$ values.

The pyrimidine ring can be synthesized by several methodologies. ${ }^{19}$ Usually, a Michael reaction intermediate and a uronium derivative are condensed in basic medium. This reaction results in an alicyclic derivative that can be converted into pyrimidine or the pyrimidinone ring, depending on the nature of the uronium derivative..$^{20}$ This reaction can be carried out via multicomponent synthesis (MCRs). ${ }^{21}$ In these procedures, three or more reagents are mixed together to obtain a single product, leading to better overall yields and shorter reaction times. ${ }^{22}$

Thiopyrimidinones are an intriguing class of pyrimidinones. These compounds present a particular tautomeric equilibrium due to double bonds conjugated to heteroatoms inside and outside of the heterocycle. The most notorious compound in this family is thiouracil, a bioactive thiopyrimidinone closely related to uracil. ${ }^{23,24}$ Thiouracil derivatives are well reported in the literature because of their pharmacological properties. ${ }^{21,25,26}$

We have decided to synthesize thiopyrimidinone derivatives, and to conduct in vitro studies to assess AR inhibition as part of our research program aiming to develop new drug candidates for aldose reductase inhibition. These efforts were combined with molecular docking simulations to better understand ligand-enzyme binding modes.

\section{Experimental}

\section{General information}

The reagents benzaldehyde, 4-anisaldehyde, 4-fluorobenzaldehyde, 4-tolualdehyde, ethyl bromoacetate, bromoacetic acid, bromopropionic acid, triethylamine were purchased from Sigma-Aldrich (Missouri, USA). Additionally, 4-chlorobenzaldehyde and ethyl cyanoacetate were purchased from Alfa Aesar (Massachusetts, USA); thiourea and hydrochloric acid were obtained from Merck (Darmstadt, Germany) and all organic solvents were purchased from Neon Comercial (Suzano, Brazil). All commercially available reagents were used without any further purification and the reactions were monitored by thin layer chromatography (TLC) analysis with TLC plates containing $\mathrm{F}_{254}$ (Fluka/Sigma-Aldrich, Missouri, USA) utilizing a mixture of hexane/ethyl acetate $(1: 1 \mathrm{v} / \mathrm{v})$ as eluent. ${ }^{1} \mathrm{H}$ and ${ }^{13} \mathrm{C}$ nuclear magnetic resonance (NMR) spectra were recorded with a Varian UNMRS $400 \mathrm{MHz}$ spectrometer (California, USA), employing dimethyl sulfoxide (DMSO- $d_{6}$ ) as solvent. Melting points were determined using the Electro-thermal (Staffordshire, UK) equipment model Mel-Temp of the analog type and were not corrected. High resolution mass spectra (HRMS) were recorded on a Bruker Daltonics-microTOF spectrometer 
(Massachusetts, USA). The 2-thiopyrimidin-4-ones $4 \mathbf{a}-4 \mathbf{e},,^{27,28} 5 \mathbf{a}-5 \mathbf{e},{ }^{29-31} \mathbf{6} \mathbf{a}^{32}$ and $\mathbf{6} \mathbf{c}^{33}$ were fully characterized and their data were compared to the literature.

General procedure for the synthesis of 6-aryl-4-oxo-2-thioxo1,2,3,4-tetrahydropyrimidine-5-carbonitrile (4a-4e)

In a $100 \mathrm{~mL}$ round-bottom flask (wrapped with tin foil for protection against the light) a mixture of aromatic aldehyde $(10 \mathrm{mmol})$, ethyl cyanoacetate $(15 \mathrm{mmol})$, thiourea $(15 \mathrm{mmol})$ potassium carbonate $(15 \mathrm{mmol})$ and $50 \mathrm{~mL}$ of ethanol was stirred at room temperature and refluxed for 8 to $12 \mathrm{~h}$. Upon completion of the reaction, the mixture was poured into ice and acidified with concentrated $\mathrm{HCl}$. The precipitate was then vacuum filtered, washed with distilled water $(100 \mathrm{~mL})$, and recrystallized in a dimethylformamide (DMF)/methanol mixture.

General procedure for the synthesis of ethyl 2-[(4-aryl5-cyano-6-oxo-1,6-dihydropyrimidin-2-yl)thio]acetate $(5 \mathrm{a}-5 \mathrm{e})$

In a $50 \mathrm{~mL}$ round-bottom flask, a mixture of 6-aryl-4-oxo2-thioxo-1,2,3,4-tetrahydropyrimidine-5-carbonitrile (4a-4e) $(4.5 \mathrm{mmol}), 30 \mathrm{~mL}$ of acetone, ethyl bromoacetate 5 $(6.5 \mathrm{mmol})$ and triethylamine $(4.5 \mathrm{mmol})$ was stirred at room temperature for $2 \mathrm{~h}$. After the completion of the reaction, the mixture was poured into ice and acidified with concentrated $\mathrm{HCl}$. The precipitate was then vacuum filtered, washed with distilled water $(20 \mathrm{~mL})$, and recrystallized in an acetone/hexane mixture.

General procedure for the synthesis of 2-[(4-aryl-5-cyano6-oxo-1,6-dihydropyrimidin-2-yl)thio]acetic acid (6a-6e)

In a $25 \mathrm{~mL}$ round-bottom flask, a mixture of 6-aryl-4-oxo2-thioxo-1,2,3,4-tetrahydropyrimidine-5-carbonitrile (4a-4e) $(1.3 \mathrm{mmol}), 10 \mathrm{~mL}$ of acetone, bromoacetic acid $7(2.0 \mathrm{mmol})$ and triethylamine $(3.25 \mathrm{mmol})$ was stirred at room temperature for $5 \mathrm{~h}$. Upon completion of the reaction, the mixture was poured into ice and acidified with concentrated $\mathrm{HCl}$. The precipitate was then vacuum filtered, washed with distilled water $(20 \mathrm{~mL})$, and recrystallized from methanol.

General procedure for the synthesis of 3-((4-aryl-5-cyano6-oxo-1,6-dihydropyrimidin-2-yl)thio)propanoic acid (7a-7e)

In a $25 \mathrm{~mL}$ round-bottom flask, a mixture of 6-aryl-4-oxo2-thioxo-1,2,3,4-tetrahydropyrimidine-5-carbonitrile (4a-4e) $(0.6 \mathrm{mmol}), 10 \mathrm{~mL}$ of acetone, 3-bromopropionic acid $9(0.75 \mathrm{mmol})$ and triethylamine $(1.5 \mathrm{mmol})$ was stirred at room temperature for 8 to $12 \mathrm{~h}$. Upon completion of the reaction, the mixture was poured into ice and acidified with concentrated $\mathrm{HCl}$. The precipitate was then vacuum filtered, washed with distilled water $(20 \mathrm{~mL})$, and recrystallized from methanol.

Spectral data of the products

Ethyl 2-[(5-cyano-6-oxo-4-phenyl-1,6-dihydropyrimidin-2-yl) thio]acetate (5a)

Yield: 80\%; white solid; mp 232-234 ${ }^{\circ} \mathrm{C} ;{ }^{1} \mathrm{H}$ NMR $\left(400 \mathrm{MHz}, \mathrm{DMSO}-d_{6}\right) \delta 1.09\left(\mathrm{t}, J 7.1 \mathrm{~Hz}, 3 \mathrm{H}, \mathrm{CH}_{3}\right), 4.06$ (q, J 7.1 Hz, 2H, O-CH ${ }_{2}$ ), 4.12 (s, 2H, S-CH ${ }_{2}$ ), 7.54-7.63 $\left(\mathrm{m}, 3 \mathrm{H}, \mathrm{H}_{\mathrm{Ar}}\right), 7.89-7.91\left(\mathrm{~m}, 2 \mathrm{H}, \mathrm{H}_{\mathrm{Ar}}\right) ;{ }^{13} \mathrm{C} \mathrm{NMR}(101 \mathrm{MHz}$, DMSO- $\left.d_{6}\right) \delta 13.8,32.9,61.3,93.1,115.7,128.5,128.6$, 131.9, 135.0, 161.0, 165.2, 167.0, 168.0.

Ethyl 2-[(5-cyano-6-oxo-4-(p-tolyl)-1,6-dihydropyrimidin-2-yl) thio]acetate $\mathbf{( 5 b})$

Yield: $90 \%$; yellow solid; mp $230{ }^{\circ} \mathrm{C}$ (dec); ${ }^{1} \mathrm{H}$ NMR $\left(400 \mathrm{MHz}, \mathrm{DMSO}-d_{6}\right) \delta 1.11\left(\mathrm{t}, J 7.1 \mathrm{~Hz}, 3 \mathrm{H}, \mathrm{CH}_{3}\right), 2.39$ (s, 3H, Ph- $\mathrm{CH}_{3}$ ), 4.07 (q, J 7.1 Hz, 2H, O-CH ${ }_{2}$ ), 4.12 (s, $\left.2 \mathrm{H}, \mathrm{S}-\mathrm{CH}_{2}\right), 7.37\left(\mathrm{~d}, J 8.1 \mathrm{~Hz}, 2 \mathrm{H}, \mathrm{H}_{\mathrm{Ar}}\right), 7.83(\mathrm{~d}, J 8.1 \mathrm{~Hz}$, $\left.2 \mathrm{H}, \mathrm{H}_{\mathrm{Ar}}\right) ;{ }^{13} \mathrm{C}$ NMR (101 MHz, DMSO- $\left.d_{6}\right) \delta 13.9,21.0$, $32.9,61.3,92.5,115.8,128.7,129.0,132.1,142.3,161.1$, $164.9,166.7,168.0$.

Ethyl 2-[(5-cyano-4-(4-methoxyphenyl)-6-oxo-1,6-dihydropyrimidin-2-yl)thio]acetate (5c)

Yield: $83 \%$; white solid; mp $194-196{ }^{\circ} \mathrm{C}$; ${ }^{1} \mathrm{H}$ NMR $\left(400 \mathrm{MHz}, \mathrm{DMSO}-d_{6}\right) \delta 1.12\left(\mathrm{t}, J 7.1 \mathrm{~Hz}, 3 \mathrm{H}, \mathrm{CH}_{3}\right), 3.85$ (s, $\left.3 \mathrm{H}, \mathrm{O}-\mathrm{CH}_{3}\right), 4.08\left(\mathrm{q}, J 7.1 \mathrm{~Hz}, 2 \mathrm{H}, \mathrm{O}-\mathrm{CH}_{2}\right), 4.13$ (s, $\left.2 \mathrm{H}, \mathrm{S}-\mathrm{CH}_{2}\right), 7.10\left(\mathrm{~d}, J 8.9 \mathrm{~Hz}, 2 \mathrm{H}, \mathrm{H}_{\mathrm{Ar}}\right), 7.97(\mathrm{~d}, J 8.9 \mathrm{~Hz}$, $\left.2 \mathrm{H}, \mathrm{H}_{\mathrm{Ar}}\right) ;{ }^{13} \mathrm{C}$ NMR (101 MHz, DMSO- $\left.d_{6}\right) \delta 13.9,32.9$, 55.5, 61.3, 91.4, 113.9, 116.1, 126.9, 130.8, 161.1, 162.4, $164.4,166.0,168.0$.

Ethyl 2-[(5-cyano-4-(4-fluorophenyl)-6-oxo-1,6-dihydropyrimidin-2-yl)thio]acetate (5d)

Yield: $70 \%$; white solid; mp 228-230 ${ }^{\circ} \mathrm{C}$; ${ }^{1} \mathrm{H}$ NMR $\left(400 \mathrm{MHz}, \mathrm{DMSO}-d_{6}\right) \delta 1.08\left(\mathrm{t}, J 7.1 \mathrm{~Hz}, 3 \mathrm{H}, \mathrm{CH}_{3}\right), 4.06$ (q, J 7.1 Hz, 2H, O-CH ${ }_{2}$ ), 4.13 (s, 2H, S-CH ${ }_{2}$ ), 7.39-7.44 $\left(\mathrm{m}, 2 \mathrm{H}, \mathrm{H}_{\mathrm{Ar}}\right), 7.97-8.01\left(\mathrm{~m}, 2 \mathrm{H}, \mathrm{H}_{\mathrm{Ar}}\right) ;{ }^{13} \mathrm{C} \mathrm{NMR}(101 \mathrm{MHz}$, DMSO- $\left._{6}\right) \delta 13.9,33.0,61.3,93.0,115.5,115.8,131.3$, 131.4, 161.0, 162.9, 165.2, 165.8, 168.0.

Ethyl 2-[(4-(4-chlorophenyl)-5-cyano-6-oxo-1,6-dihydropyrimidin-2-yl)thio]acetate (5e)

Yield: 64\%; yellow solid; mp $215^{\circ} \mathrm{C}$ (dec); ${ }^{1} \mathrm{H}$ NMR $\left(400 \mathrm{MHz}, \mathrm{DMSO}-d_{6}\right) \delta 1.08\left(\mathrm{t}, J 6.9 \mathrm{~Hz}, 3 \mathrm{H}, \mathrm{CH}_{3}\right), 4.06$ 
(q, J $\left.6.9 \mathrm{~Hz}, 2 \mathrm{H}, \mathrm{O}-\mathrm{CH}_{2}\right), 4.12\left(\mathrm{~s}, 2 \mathrm{H}, \mathrm{S}-\mathrm{CH}_{2}\right), 7.64$ (d, $\left.J 8.3 \mathrm{~Hz}, 2 \mathrm{H}, \mathrm{H}_{\mathrm{Ar}}\right), 7.92\left(\mathrm{~d}, J 8.3 \mathrm{~Hz}, 2 \mathrm{H}, \mathrm{H}_{\mathrm{Ar}}\right) ;{ }^{13} \mathrm{C} \mathrm{NMR}$ $\left(101 \mathrm{MHz}, \mathrm{DMSO}-d_{6}\right) \delta 13.9,33.0,61.3,93.3,115.5,128.6$, $130.5,133.7,136.8,160.9,165.4,165.7,167.9$.

2-[(5-Cyano-6-oxo-4-phenyl-1,6-dihydropyrimidin-2-yl)thio] acetic acid (6a)

Yield: 52\%; yellow solid; mp 218-220 ${ }^{\circ} \mathrm{C} ;{ }^{1} \mathrm{H}$ NMR (400 MHz, DMSO-d $)_{6} \delta 4.05\left(\mathrm{~s}, 2 \mathrm{H}, \mathrm{CH}_{2}\right), 7.63-7.52(\mathrm{~m}$, $\left.3 \mathrm{H}, \mathrm{H}_{\mathrm{Ar}}\right), 7.97-7.91\left(\mathrm{~m}, 2 \mathrm{H}, \mathrm{H}_{\mathrm{Ar}}\right) ;{ }^{13} \mathrm{C} \mathrm{NMR}(101 \mathrm{MHz}$, DMSO- $\left.d_{6}\right) \delta 33.3,93.1,115.9,128.7,128.9,132.0,135.1$, 161.2, 165.5, 167.2, 169.3.

2-[(5-Cyano-6-oxo-4-(p-tolyl)-1,6-dihydropyrimidin-2-yl)thio] acetic acid (6b)

Yield: 60\%; white solid; mp 228-230 ${ }^{\circ} \mathrm{C} ;{ }^{1} \mathrm{H}$ NMR (400 MHz, DMSO- $d_{6}$ ) $\delta 2.39\left(\mathrm{~s}, 3 \mathrm{H}, \mathrm{CH}_{3}\right), 4.05$ (s, 2H, $\left.\mathrm{CH}_{2}\right), 7.36\left(\mathrm{~d}, J 7.9 \mathrm{~Hz}, 2 \mathrm{H}, \mathrm{H}_{\mathrm{Ar}}\right), 7.87\left(\mathrm{~d}, J 7.9 \mathrm{~Hz}, 2 \mathrm{H}, \mathrm{H}_{\mathrm{Ar}}\right)$; ${ }^{13} \mathrm{C}$ NMR (101 MHz, DMSO- $\left.d_{6}\right) \delta 21.1,33.1,92.4,115.9$, 128.8, 129.1, 132.2, 142.3, 161.1, 165.2, 166.9, 169.2; HRMS $m / z$, calcd. for $\mathrm{C}_{14} \mathrm{H}_{11} \mathrm{~N}_{3} \mathrm{O}_{3} \mathrm{~S}[\mathrm{M}+\mathrm{H}]^{+}:$302.0599, found: 302.0591 .

2-[(5-Cyano-4-(4-methoxyphenyl)-6-oxo-1,6-dihydropyrimidin-2-yl)thio]acetic acid (6c)

Yield: 48\%; white solid; mp 197-200 ${ }^{\circ} \mathrm{C} ;{ }^{1} \mathrm{H}$ NMR (400 MHz, DMSO- $d_{6}$ ) $\delta 3.85$ (s, 3H, O-CH ) $_{3} 4.05$ (s, 2H, $\left.\mathrm{CH}_{2}\right)$, 7.08-7.14 (m, 2H, $\mathrm{H}_{\mathrm{Ar}}$ ), 7.99-8.06 (m, $2 \mathrm{H}, \mathrm{H}_{\mathrm{Ar}}$ ).

2-[(5-Cyano-4-(4-fluorophenyl)-6-oxo-1,6-dihydropyrimidin2-yl)thio]acetic acid (6d)

Yield: 60\%; white solid; mp 202-205 ${ }^{\circ} \mathrm{C}$; ${ }^{1} \mathrm{H}$ NMR $\left(400 \mathrm{MHz}, \mathrm{DMSO}-d_{6}\right) \delta 4.06\left(\mathrm{~s}, 2 \mathrm{H}, \mathrm{CH}_{2}\right), 7.40(\mathrm{~m}, 2 \mathrm{H}$, $\left.\mathrm{H}_{\mathrm{Ar}}\right), 8.03\left(\mathrm{~m}, 2 \mathrm{H}, \mathrm{H}_{\mathrm{Ar}}\right) ;{ }^{13} \mathrm{C} \mathrm{NMR}\left(101 \mathrm{MHz}, \mathrm{DMSO}-d_{6}\right)$ $\delta 29.1,88.9,111.6,111.8,127.5,127.6,157.0,158.9$, 161.4, 161.8, 165.2; HRMS $m / z$, calcd. for $\mathrm{C}_{13} \mathrm{H}_{8} \mathrm{FN}_{3} \mathrm{O}_{3} \mathrm{~S}$ $[\mathrm{M}+\mathrm{H}]^{+}:$306.0349, found: 306.0342 .

2-[(4-(4-Chlorophenyl)-5-cyano-6-oxo-1,6-dihydropyrimidin2-yl)thio]acetic acid (6e)

Yield: 65\%; white solid; mp $230{ }^{\circ} \mathrm{C}$ (dec); ${ }^{1} \mathrm{H}$ NMR (400 MHz, DMSO- $\left.d_{6}\right) \delta 4.05\left(\mathrm{~s}, 2 \mathrm{H}, \mathrm{CH}_{2}\right), 7.60-7.67$ (m, $\left.2 \mathrm{H}, \mathrm{H}_{\mathrm{Ar}}\right), 7.92-8.00\left(\mathrm{~m}, 2 \mathrm{H}, \mathrm{H}_{\mathrm{Ar}}\right) ;{ }^{13} \mathrm{C} \mathrm{NMR}(101 \mathrm{MHz}$, DMSO- $\left.d_{6}\right) \delta 33.2,93.2,115.6,128.7,130.6,133.9$, 136.8, 160.9, 165.7, 165.8, 169.2; HRMS $m / z$, calcd. for $\mathrm{C}_{13} \mathrm{H}_{8} \mathrm{ClN}_{3} \mathrm{O}_{3} \mathrm{~S}[\mathrm{M}+\mathrm{H}]^{+}:$322.0053, found: 322.0050 .

3-[(5-Cyano-6-oxo-4-phenyl-1,6-dihydropyrimidin-2-yl)thio] propanoic acid (7a)

Yield: $45 \%$; yellow solid; mp $240{ }^{\circ} \mathrm{C}$ (dec); ${ }^{1} \mathrm{H}$ NMR $\left(400 \mathrm{MHz}, \mathrm{DMSO}-d_{6}\right) \delta 2.75\left(\mathrm{t}, J 6.7 \mathrm{~Hz}, 2 \mathrm{H}, \mathrm{CH}_{2}-\mathrm{COOH}\right)$, $3.39\left(\mathrm{t}, J 6.7 \mathrm{~Hz}, 2 \mathrm{H}, \mathrm{S}-\mathrm{CH}_{2}\right), 7.54-7.63\left(\mathrm{~m}, 3 \mathrm{H}, \mathrm{H}_{\mathrm{Ar}}\right.$ ), 7.98-7.86 (m, 2H, $\left.\mathrm{H}_{\mathrm{Ar}}\right) ;{ }^{13} \mathrm{C}$ NMR (101 MHz, DMSO- $\left.d_{6}\right)$ $\delta 25.8,33.5,93.1,115.9,128.6,128.7,131.8,135.3,161.1$, 165.9, 167.2, 172.7; HRMS $m / z$, calcd. for $\mathrm{C}_{14} \mathrm{H}_{11} \mathrm{~N}_{3} \mathrm{O}_{3} \mathrm{~S}$ $[\mathrm{M}+\mathrm{H}]^{+}:$302.0599, found: 302.0586 .

3-[(5-Cyano-6-oxo-4-(p-tolyl)-1,6-dihydropyrimidin-2-yl)thio] propanoic acid $(\mathbf{7 b})$

Yield: 58\%; white solid; mp 220-223 ${ }^{\circ} \mathrm{C}$; ${ }^{1} \mathrm{H}$ NMR $\left(400 \mathrm{MHz}, \mathrm{DMSO}-d_{6}\right) \delta 2.39\left(\mathrm{~s}, 3 \mathrm{H}, \mathrm{CH}_{3}\right), 2.74(\mathrm{t}, J 6.6 \mathrm{~Hz}$, $\left.2 \mathrm{H}, \mathrm{CH}_{2}-\mathrm{COOH}\right), 3.39$ (t, J $\left.6.6 \mathrm{~Hz}, 2 \mathrm{H}, \mathrm{S}-\mathrm{CH}_{2}\right), 7.36$ (d, $\left.J 7.9 \mathrm{~Hz}, 2 \mathrm{H}, \mathrm{H}_{\mathrm{Ar}}\right), 7.86\left(\mathrm{~d}, J 7.9 \mathrm{~Hz}, 2 \mathrm{H}, \mathrm{H}_{\mathrm{Ar}}\right) ;{ }^{13} \mathrm{C} \mathrm{NMR}$ $\left(101 \mathrm{MHz}, \mathrm{DMSO}-d_{6}\right) \delta 21.1,25.8,33.5,92.5,116.0$, 128.7, 129.2, 132.4, 142.2, 161.1, 165.5, 167.0, 172.7; HRMS $m / z$, calcd. for $\mathrm{C}_{15} \mathrm{H}_{13} \mathrm{~N}_{3} \mathrm{O}_{3} \mathrm{~S}[\mathrm{M}+\mathrm{H}]^{+}:$316.0756, found: 316.0746 .

3-[(5-Cyano-4-(4-methoxyphenyl)-6-oxo-1,6-dihydropyrimidin-2-yl)thio]propanoic acid (7c)

Yield: 75\%; yellow solid; mp 205-208 ${ }^{\circ} \mathrm{C}$; ${ }^{1} \mathrm{H}$ NMR (400 MHz, DMSO- $\left.d_{6}\right) \delta 2.74\left(\mathrm{t}, J 6.7 \mathrm{~Hz}, 2 \mathrm{H}, \mathrm{CH}_{2}-\mathrm{COOH}\right)$, 3.40 (t, J 6.7 Hz, 2H, S- $\mathrm{CH}_{2}$ ), 3.85 (s, 3H, $\mathrm{CH}_{3}$ ), 7.10 (d, $\left.J 8.9 \mathrm{~Hz}, 2 \mathrm{H}, \mathrm{H}_{\mathrm{Ar}}\right), 8.00\left(\mathrm{~d}, J 8.9 \mathrm{~Hz}, 2 \mathrm{H}, \mathrm{H}_{\mathrm{Ar}}\right) ;{ }^{13} \mathrm{C} \mathrm{NMR}$ $\left(101 \mathrm{MHz}, \mathrm{DMSO}-d_{6}\right) \delta 25.8,33.5,55.5,91.4,114.0$, 116.3, 127.2, 130.8, 161.2, 162.3, 165.1, 166.2, 172.8; HRMS $m / z$, calcd. for $\mathrm{C}_{15} \mathrm{H}_{13} \mathrm{~N}_{3} \mathrm{O}_{4} \mathrm{~S}[\mathrm{M}+\mathrm{H}]^{+}:$332.0705, found: 332.0692 .

3-[(5-Cyano-4-(4-fluorophenyl)-6-oxo-1,6-dihydropyrimidin2-yl)thio]propanoic acid (7d)

Yield: 64\%; white solid; mp 218-220 ${ }^{\circ} \mathrm{C}$; ${ }^{1} \mathrm{H}$ NMR $\left(400 \mathrm{MHz}, \mathrm{DMSO}-d_{6}\right) \delta 2.74\left(\mathrm{t}, J 6.6 \mathrm{~Hz}, 2 \mathrm{H}, \mathrm{CH}_{2}-\mathrm{COOH}\right)$, $3.39\left(\mathrm{t}, J 6.7 \mathrm{~Hz}, 2 \mathrm{H}, \mathrm{S}-\mathrm{CH}_{2}\right), 7.36-7.45\left(\mathrm{~m}, 2 \mathrm{H}, \mathrm{H}_{\mathrm{Ar}}\right)$, 8.07-7.99 (m, 2H, $\left.\mathrm{H}_{\mathrm{Ar}}\right) ;{ }^{13} \mathrm{C}$ NMR (101 MHz, DMSO- $\left.d_{6}\right)$ $\delta 25.8,33.5,93.0,115.6,115.8,131.4,131.4,161.0,162.8$, 165.3, 165.9, 172.7; HRMS $m / z$, calcd. for $\mathrm{C}_{14} \mathrm{H}_{10} \mathrm{FN}_{3} \mathrm{O}_{3} \mathrm{~S}$ $[\mathrm{M}+\mathrm{H}]^{+}:$320.0505, found: 320.0494 .

3-[(4-(4-Chlorophenyl)-5-cyano-6-oxo-1,6-dihydropyrimidin2-yl)thio]propanoic acid (7e)

Yield: 45\%; yellow solid; mp 210-212 ${ }^{\circ} \mathrm{C}$; ${ }^{1} \mathrm{H}$ NMR (400 MHz, DMSO- $\left.d_{6}\right) \delta 2.73\left(\mathrm{t}, J 6.7 \mathrm{~Hz}, 2 \mathrm{H}, \mathrm{CH}_{2}-\mathrm{COOH}\right)$, 3.39 (t, J 6.7 Hz, 2H, S-CH $\mathrm{CH}_{2}, 7.64$ (d, J $8.6 \mathrm{~Hz}, 2 \mathrm{H}, \mathrm{H}_{\mathrm{Ar}}$ ), $7.96\left(\mathrm{~d}, J 8.6 \mathrm{~Hz}, 2 \mathrm{H}, \mathrm{H}_{\mathrm{Ar}}\right) ;{ }^{13} \mathrm{C} \mathrm{NMR}\left(101 \mathrm{MHz}, \mathrm{DMSO}-d_{6}\right)$ $\delta$ 25.8, 33.5, 93.2, 115.7, 128.7, 130.5, 134.0, 136.6, 161.0, 166.0, 166.1, 172.7; HRMS $m / z$, calcd. for $\mathrm{C}_{14} \mathrm{H}_{10} \mathrm{ClN}_{3} \mathrm{O}_{3} \mathrm{~S}$ $[\mathrm{M}+\mathrm{H}]^{+}:$336.0210, found: 336.0203 .

Aldose reductase in vitro assays

The experiments were performed using the aldose 
reductase inhibitor screening kit by Biovision Incorporated ${ }^{\odot}$ (Milpitas, USA). The series of compounds 5a-5e, 6a-6e and 7a-7e were tested as AR inhibitors. The assays were carried out, as per the kit manual, in a 96-round bottom transparent microplate (Thermo Scientific, Massachusetts, USA) and data were acquired using BIOTEK $^{\odot}$ (Vermont, USA) ELx808 absorbance spectrophotometer at $340 \mathrm{~nm}$.

Stock solutions were prepared as described by the kit manual for each component. Dithiothreitol (DTT) stock solution $(10 \mathrm{mM})$ was prepared using $2 \mu \mathrm{L}$ of $1 \mathrm{M}$ DTT diluted in $198 \mu \mathrm{L}$ of ultrapure water. Then, the assay buffer solution containing DTT was prepared using $2 \mu \mathrm{L}$ of DTT stock solution in $1998 \mu \mathrm{L}$ of assay buffer provided in the kit. Aldose reductase was firstly reconstituted with $100 \mu \mathrm{L}$ of assay buffer containing $10 \mu \mathrm{M}$ DTT. Then, aliquots of $6 \mu \mathrm{L}$ were made and stored at $-80^{\circ} \mathrm{C}$. To prepare the AR working solution, each $6 \mu \mathrm{L}$ of AR stock solution aliquots were mixed with $534 \mu \mathrm{L}$ of assay buffer containing $10 \mu \mathrm{M}$ DTT. The AR cofactor NADPH (nicotinamide adenine dinucleotide phosphate) stock solution $(20 \mathrm{mM})$ was obtained after reconstitution with $440 \mu \mathrm{L}$ of ultrapure water. Then, aliquots of $20 \mu \mathrm{L}$ were made and stocked at $-20^{\circ} \mathrm{C}$. To prepare the NADPH working solution, each $20 \mu \mathrm{L}$ of NADPH stock solution aliquots were mixed with $340 \mu \mathrm{L}$ of assay buffer.

All fifteen compounds (5a-5e; 6a-6e and 7a-7e) were at first tested at the same concentration of $50 \mu \mathrm{M}$. Then, some of these compounds were tested at different concentrations (i.e., $0.05,0.5,2.5,5.0,25,40$, and $60 \mu \mathrm{M}$ ) to provide a dose-response inhibition curve and to measure the half maximal inhibitory concentration $\left(\mathrm{IC}_{50}\right)$. In this case, in order to prepare test samples (S) for each compound, $50 \mathrm{mM}$ stock solutions were prepared in DMSO. Then 100x and $20 \times$ dilutions were prepared for each concentration to be tested. For example, to prepare the test sample for $50 \mu \mathrm{M}, 100 \times$ concentrated solutions $(5 \mathrm{mM})$ were made by dilution of $5 \mu \mathrm{L}$ of respective $50 \mathrm{mM}$ stock solution with $45 \mu \mathrm{L}$ of DMSO. Then, the dilution of $10 \mu \mathrm{L}$ of $100 \times$ solutions with $40 \mu \mathrm{L}$ of assay buffer was used to prepare the $20 \times$ working solution.

As indicated by the kit manual, control samples were prepared as follows: the background control (BC) is deprived of the AR enzyme and inhibitor, and we replaced its volume $(100 \mu \mathrm{L})$ with AR buffer. Enzyme control (EC) is deprived of the inhibitor, and we replaced its volume $(10 \mu \mathrm{L})$ with AR buffer. The inhibitor control (IC) was prepared by a $100 \times$ dilution of $10 \mathrm{mM}$ Epalrestat $(72 \mathrm{nM})$ in assay buffer to a final concentration of $5 \mu \mathrm{M}$. The solvent control (SC) was prepared by the same $20 \times$ dilution in assay buffer as described for test samples to certify that samples' solvent (DMSO) will not interfere in AR activity. With all working solutions prepared, the reaction components were added to a 96-well plate in the following order: $100 \mu \mathrm{L}$ of assay buffer in the BC well, $10 \mu \mathrm{L}$ of assay buffer in the EC well, $10 \mu \mathrm{L}$ of $100 \times$ diluted Epalrestat in the IC well, $10 \mu \mathrm{L}$ of $20 \times$ diluted DMSO in the SC well, and $10 \mu \mathrm{L}$ of each $20 \times$ working solution for each compound to be tested (5a-5e; 6a-6e and 7a-7e). After that, $60 \mu \mathrm{L}$ of NADPH working solution was added to all wells, whereas $90 \mu \mathrm{L}$ of AR working solution was added to all wells except the BC well. The 96-well plate was then incubated at $37{ }^{\circ} \mathrm{C}$ for $20 \mathrm{~min}$. Finally, the substrate solution was prepared by mixing $4 \mu \mathrm{L}$ of AR substrate with $36 \mu \mathrm{L}$ of assay buffer, with the final volume $(40 \mu \mathrm{L})$ being added to each well after incubation time, resulting in a final total volume of $200 \mu \mathrm{L}$ in each well for all compounds and control samples. Tests were done in duplicate and absorbances were immediately measured in kinetic mode for 60 min with 1 min interval at $37{ }^{\circ} \mathrm{C}$. As described by the kit manual, two periods of time $\left(t_{1}\right.$ and $\left.t_{2}\right)$ were chosen from absorbance over time curves and each slope was calculated using the respective absorbances $\left(A_{1}\right.$ and $\left.A_{2}\right)$. Then, the following equation was used to calculate the relative inhibition percentage (equation 1).

Relative inhibition $(\%)=\frac{\mid \text { slope of }(\mathrm{EC})-\text { slope of }(\mathrm{S}) \mid}{\mid \text { slope of }(\mathrm{EC}) \mid} \times 100$

Relative inhibition percentage calculation of the tested compounds as aldose reductase inhibitors, where EC: enzymatic control; S: sample.

\section{Molecular docking}

In order to assess the binding modes of the described compounds (5a-5e, 6a-6e and 7a-7e) at the aldose reductase active site, molecular docking simulations were performed using AutoGrid v.4.0 $0^{34}$ and AutoDock ${ }^{35}$ v.4. $.0^{36,37}$ as described in our previous works. ${ }^{38,39}$ Crystallographic structures with different conformations at AR active site were obtained from $\mathrm{PDB}^{40}$ (3DN5, 2FZD, 2NVD and 1US0). Enzymes were treated as rigid, while the respective ligands were treated as flexible. To prepare the enzymes for simulations, polar hydrogens were added and partial charges for protein atoms were assigned according to AMBER86 force field parameters, ${ }^{41}$ which were assigned to all atoms. To prepare ligands (cocrystallized ligands or target compounds), charges were assigned by Gasteiger method to certify that all residues presented integer charges. In order to evaluate the reproducibility of our simulation procedure, a validation method was arranged (commonly called redocking) to prove that the procedure can reproduce 
the structural conformation of the cocrystallized ligand at the active site of the respective enzymes tested. These experiments were conducted with the ligands slightly outside the active site but still placed in a grid box, using 200 simulation steps. Redocking results were compared to the initial coordinates of the cocrystallized ligands to validate the methodology and it was successful. A grid with dimensions of $28 \AA \times 28 \AA \times 28 \AA$ and spacing of $0.22 \AA$ was centered at coordinates $16.691,-7.611,13.869$. All structures were superimposed to 2FZD to simplify the analysis of the results.

The binding modes for all the ligands were predicted based on affinity maps generated by AutoGrid v4.0, all affinity maps were calculated using the same settings. The Lamarckian genetic algorithm ${ }^{42,43}$ was employed for molecular docking simulations using the following parameters: an initial population of 150 individuals/ generation, a maximum number of 27000 generations, and a total of $2.5 \times 10^{6}$ energy evaluation/generation. Thus, a total of $4.05 \times 10^{6}$ conformations for each of the ligands were generated in each of the 200 steps of the simulation. An elitism rate of 1 was applied to ensure that the top individual always survives into the next generation in conjunction with mutation and crossover rates of 0.02 and 0.08 , respectively. In the local search, 300 steps were applied with a 0.06 probability of searching for one individual. At the end of the calculation at each simulation step, the ligand conformations that have the most favorable binding energy were selected, so that the atomic coordinates of the 200 conformers that better fit the binding site were obtained. All obtained conformers were structurally compared through their root mean square deviations (RMSDs), and clustered into groups of similar conformations with a RMSD tolerance of $2 \AA$ for each cluster. Structures and figures were examined and generated by PyMOL. ${ }^{44}$

\section{Results and Discussion}

\section{Chemistry}

Our strategy began with the selection of the 2-thiopyrimidin-4-one as a scaffold for AR inhibitor candidates. A literature review showed that good AR inhibitors contain multiple aromatic systems, fused or conjugated, and at least one carbonyl portion., ${ }^{2,-11}$ Thus, we decided to perform modifications on the uronium moiety of the pyrimidinone ring, and then study how the $S$-substitution pattern can influence AR inhibition in vitro. The key step for the synthesis of new AR inhibitors was the functionalization of the 2-thiopyrimidin-4-one ring via $S$-alkylation. Parent compounds 6-aryl-4-oxo-2-thioxo1,2,3,4-tetrahydropyrimidine-5-carbonitriles were prepared using a multicomponent approach, in which different aromatic aldehydes (1a-1e), ethyl cyanoacetate (2) and thiourea (3) reacted under reflux in alkaline media. ${ }^{28,45-47}$ From 2-thiopyrimidin-4-ones $4 \mathbf{a}-\mathbf{4 e}$, three series of $S$-alkylated derivatives were prepared. The use of ethyl bromoacetate yielded the products 5a-5e. Bromoacetic acid as the alkylating agent resulted in the synthesis of series 6a-6e. Finally, acids 7a-7e were produced by using bromopropionic acid (Scheme 1).

The multicomponent reaction mechanism for the formation of the pyrimidine ring has been described by de Andrade et al. ${ }^{21}$ The synthesis begins with a Knoevenagel reaction between the methylene-active compound (ethyl cyanoacetate) and the aldehyde, producing the Michael reaction intermediate. This step is base-mediated and a water molecule is lost. The Michael reaction intermediate then reacts with thiourea, forming a uronium intermediate. Then, an intramolecular attack of a nitrogen electron pair occurs, thus closing the ring; in this step, an ethanol<smiles>[R]c1ccc(C=O)cc1</smiles>

1a-1e

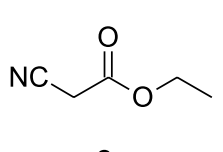

2

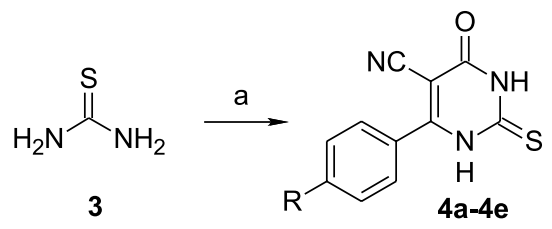<smiles>[R]c1ccc(-c2[nH]c(=S)[nH]c(=O)c2C#N)cc1</smiles><smiles>[R]C(=O)CSc1nc(-c2ccc([R])cc2)c(C#N)c(=O)[nH]1</smiles>

$$
\begin{aligned}
& \text { 5a-5e }\left(n=1, X=\mathrm{CH}_{2} \mathrm{CH}_{3}\right) \\
& \text { 6a-6e }(n=1, X=H) \\
& \text { 7a-7e }(n=2, X=H)
\end{aligned}
$$

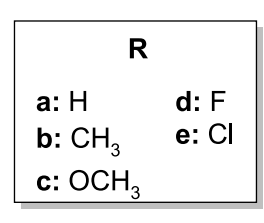

Scheme 1. Reagents and conditions: (a) $\mathrm{K}_{2} \mathrm{CO}_{3}$, EtOH/ $\mathrm{H}_{2} \mathrm{O}$, reflux; (b) ethyl bromoacetate (5a-5e), bromoacetic acid (6a-6e) or bromopropionic acid (7a-7e); triethylamine, acetone, room temperature. 
molecule is eliminated. Finally, the oxidation of the pyrimidine ring is carried out by atmospheric oxygen leading to the final product. ${ }^{48}$

For the functionalization of 2-thiopyrimidin-4-ones 4a-4e, $S$-alkylation reactions were performed using a combination of triethylamine and acetone. This system was chosen from a series of experiments seeking the best synthetic strategy with different classical reaction conditions (Table 1) using 4a and ethyl bromoacetate. This method led to the exclusive formation of the product of interest (5a). The approach was then replicated for functionalization on the other series: one containing an acetic acid portion (6a-6e) and the other containing a propionic acid moiety (7a-7e). This shows that the same reaction conditions proved to be effective for the heterocycle functionalization with other alkylating agents.

Table 1. Tested conditions for the $S$-alkylation of 2-thiopyrimidin-4-ones

\begin{tabular}{lccc}
\hline entry & Base & Solvent & Yield / \% \\
\hline 1 & $\mathrm{~K}_{2} \mathrm{CO}_{3}$ & DMF & $\mathrm{a}$ \\
2 & $\mathrm{Et}_{3} \mathrm{~N}$ & acetone & 55 \\
3 & pyridine & pyridine & 45 \\
4 & AcONa & ethanol & ${ }^{a}$ \\
\hline
\end{tabular}

a Since many by-products were observed in TLC, the product was not purified and/or isolated. DMF: dimethylformamide.

The reaction with ethyl bromoacetate generated five products alkylated exclusively on the sulfur atom $(\mathbf{5 a - 5 e})$; in other words, no $N$ or $O$-alkylated products were observed. Although the thiol form is not the predominant one in equilibrium, this reaction is possible due to the thiol/thione tautomeric equilibrium in 2-thiopyrimidin-4-ones, very similar to the keto/enol tautomerism. ${ }^{49}$

The particular tautomeric equilibrium present in 2-thiopyrimidin-4-ones is due to the proton mobility in the uronium moiety of the heterocycle. Martos-Calvente et al. ${ }^{24}$ showed that this equilibrium can be disturbed, with one tautomer being favored over another, and it can be affected by several factors, such as: physical state, solvent, temperature, $\mathrm{pH}$ and concentration. Several techniques, such as infrared, NMR and UV-Vis have shown this type of tautomerism. It is known that in the solid state, for example, the thione form is favored. In the liquid phase, the solvent plays an important role in the thiol/thione formation rate. Solvents with a high dielectric constant favor the thione form, while solvents with low dielectric constant favor the thiol tautomer. ${ }^{23}$

The preference for nucleophilic attack in equilibrium prevails in the sulfur region over nitrogen atoms. Sulfur is a larger and softer atom, which makes it more polarizable. ${ }^{50}$ These particularities explain why alkylations in 2-thiopyrimidin-4-ones occur preferentially in the sulfur atom, as reported herein (Scheme 2). Thiopyrimidinones do not solubilize in most organic solvents, but they do solubilize well in acetone. This feature, combined with the aforementioned factors, explains why acetone was the solvent of choice, even though it has intermediate polarity and a medium dielectric constant. ${ }^{51}$

\section{In vitro AR inhibition assays}

At first, the compounds 5a-5e, 6a-6e and 7a-7e were submitted to an initial trial at a fixed concentration of $50 \mu \mathrm{M}$ in duplicate..$^{48}$ All compounds showed AR inhibition percentages that varied between 53 to $100 \%$ (Table 2). The $\mathrm{IC}_{50}$ values were estimated for the canonical compounds $\mathbf{5 a}$, $\mathbf{6 a}$ and $7 \mathbf{a}$ (Table 3), tested at concentrations ranging from 0.05 to $50 \mu \mathrm{M}$. After these results, we observed that the compound 7a $\left(\mathrm{IC}_{50}=14 \mu \mathrm{M}\right)$ showed an $\mathrm{IC}_{50}$ greater than the compounds $5 \mathbf{a}\left(\mathrm{IC}_{50}=6 \mu \mathrm{M}\right)$ and $\mathbf{6 a}\left(\mathrm{IC}_{50}=8 \mu \mathrm{M}\right)$. This reveals that the elongation of the lateral chain does not favor AR inhibition in these compounds. Thus, the series 5 and $\mathbf{6}$ were chosen for a more in-depth investigation regarding $\mathrm{IC}_{50}$ values.

After this preliminary analysis (Table 2), compounds $\mathbf{5 b}$, 5d, $6 \mathbf{b}$ and $\mathbf{6 d}$ were selected to have their $\mathrm{IC}_{50}$ values estimated. In series $\mathbf{5}$, the compounds $\mathbf{5 a}\left(\mathrm{IC}_{50}=5.9 \mu \mathrm{M}\right)$ and $\mathbf{5 d}\left(\mathrm{IC}_{50}=6.4 \mu \mathrm{M}\right)$ showed lower $\mathrm{IC}_{50}$ values than the compound $\mathbf{5 b}\left(\mathrm{IC}_{50}=8.7 \mu \mathrm{M}\right)$, which means that a $p$-methyl substitution in the aromatic ring is not as favorable for AR inhibition as a $p$-F substitution. In other words, in series $\mathbf{5}$, which contains an ester derivative, the presence of an electron donating group on the aromatic ring decreased activity. Regarding series $\mathbf{6}$, compound $\mathbf{6 b}$ showed the lowest $\mathrm{IC}_{50}$ value $(2.0 \mu \mathrm{M})$, followed by compound $6 \mathbf{d}(3.3 \mu \mathrm{M})$, which is lower than the canonical $6 \mathbf{a}\left(\mathrm{IC}_{50}=8.2 \mu \mathrm{M}\right)$. Therefore, for compounds containing a $-\mathrm{CH}_{2} \mathrm{COOH}$ moiety, substitutions were more beneficial to AR inhibitory activity. These data are also presented comparatively in Figure 2.
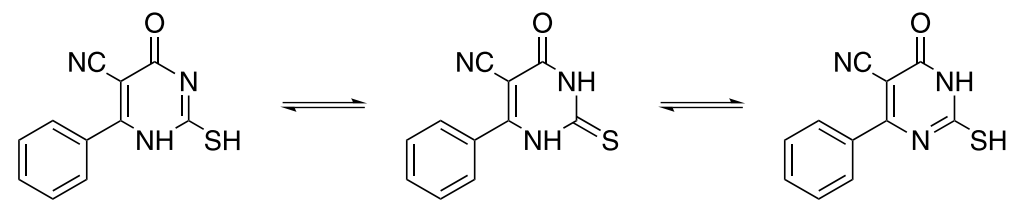

Scheme 2. Tautomeric equilibrium in 2-thiopyrimidin-4-ones. 
Table 2. Relative inhibition percentages (IP) of the compounds $\mathbf{5 a - 5 e , ~} \mathbf{6 a - 6 e}$ and $\mathbf{7 a - 7 e}$ as AR inhibitors

\begin{tabular}{|c|c|c|c|c|c|}
\hline Compound (code) & IP $/ \%$ & Compound (code) & IP / \% & Compound (code) & IP / \% \\
\hline $5 \mathbf{a}$ & 74 & $6 \mathbf{a}$ & 100 & & 85 \\
\hline $\mathbf{5 b}$ & 96 & 6b & 97 & $7 \mathbf{b}$ & 87 \\
\hline $5 c$ & 89 & 6c & 84 & $7 c$ & 91 \\
\hline 5d & 92 & 6d & 100 & $7 d$ & 87 \\
\hline $5 e$ & 88 & $6 e$ & 88 & $7 e$ & 53 \\
\hline
\end{tabular}

Table 3. $\mathrm{IC}_{50}$ values estimated for the compounds $5 \mathbf{a}, \mathbf{5 b}, \mathbf{5 d}, \mathbf{6 a}, \mathbf{6 b}, \mathbf{6 d}$ and $\mathbf{7 a}$ as $\mathrm{AR}$ inhibitors

\begin{tabular}{lc}
\hline Compound & $\mathrm{IC}_{50} / \mu \mathrm{M}$ \\
\hline $\mathbf{5 a}$ & $5.9 \pm 1.0$ \\
$\mathbf{5 b}$ & $8.7 \pm 1.0$ \\
$\mathbf{5 d}$ & $6.4 \pm 1.0$ \\
$\mathbf{7 a}$ & $14.5 \pm 1.0$ \\
$\mathbf{6 a}$ & $8.2 \pm 1.0$ \\
$\mathbf{6 b}$ & $2.0 \pm 1.0$ \\
$\mathbf{6 d}$ & $3.3 \pm 1.0$ \\
\hline $\mathrm{IC}_{50} \cdot$ half maximal inhibitory concentration.
\end{tabular}

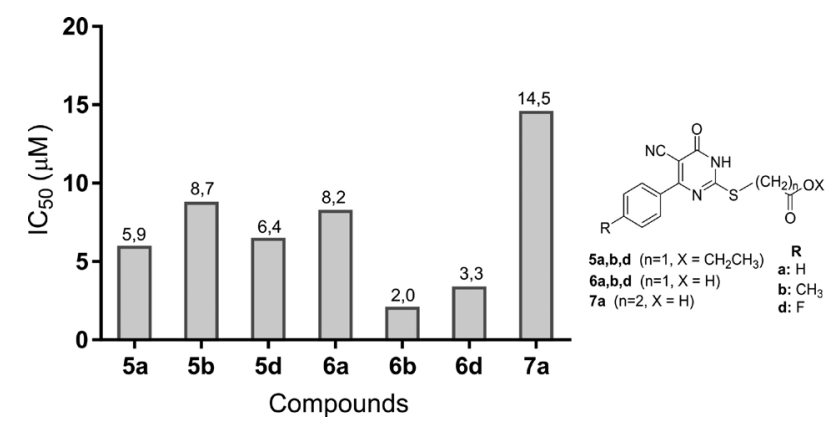

Figure 2. Experimental $\mathrm{IC}_{50}$ values for compounds $5 \mathbf{a}, \mathbf{5 b}, \mathbf{5 d}, \mathbf{6 a}, \mathbf{6 b}$, 6d and $7 \mathbf{a}$.
The comparison of the two homologous series shows that compounds from series $\mathbf{6}$ are more promising drug candidates. This fact corroborates the findings from Singh Grewal et al., ${ }^{2}$ who collected data from more than 70 carboxylic acid derivatives as AR inhibitors, demonstrating the AR enzyme affinity for this moiety. Among all these derivatives, over 55 compounds have a heterocycle moiety, and 33 compounds contain at least one sulfur atom, thus endorsing our hypothesis of testing thiopyrimidinones as AR inhibitors.

Singh Grewal et al. ${ }^{2}$ also described two fused pyrimidinones as AR inhibitors (Figure 1). The first one, an aminopyrimidinone, showed an $\mathrm{IC}_{50}$ of $34 \mu \mathrm{M} . .^{52}$ The decreased degree of rotation in comparison to the thiopyrimidinones described herein could be one of the countless factors responsible for reducing AR inhibitory activity. The second molecule does not contain a carboxylic acid moiety, but three hydroxyl substituents, which probably counterbalanced the absence of that group and allowed for increased AR inhibitory activity $\left(\mathrm{IC}_{50}=\right.$ $0.1 \mu \mathrm{M}) .{ }^{18}$ Although the thiopyrimidinones described here displayed $\mathrm{IC}_{50}$ at a low micromolar range, modifications on aromatic ring substituents (e.g., $-\mathrm{NO}_{2}$ groups or fused rings) will be further investigated to improve the 
thiopyrimidinones AR inhibitory activity to a nanomolar range.

\section{Molecular docking}

As previously stated, the AR enzyme has been studied as a target for possible inhibitors to prevent diabetic complications. Over the years, some authors ${ }^{53-57}$ have analyzed AR crystallographic structures, and investigated the main residues involved in the binding pocket. AR has been described as composed of two subpockets, one of these, known as the catalytic subpocket, comprises the residues Tyr48, Lys77, His110 and Trp111, as well as its cofactor NADPH. ${ }^{11,53,55}$ The second one, known as the specificity pocket, is formed by residues Trp111, Thr113, Phe122, Ala299 and Leu300, ${ }^{11,53-55}$ these last residues adopt different conformations that depend on ligand size and properties. ${ }^{55-57}$ Computer simulations can be used to investigate how these changes at the enzyme active site affect the multiple conformations of the crystallized structure. For this reason, we chose to perform molecular docking simulations in the following crystallographic structures: PDB ID 2FZD, 3DN5, 2NVD and 1US0. AR crystallographic structures were chosen based on works of Wang et al..$^{57}$ and Eisenmann et al. ${ }^{11}$ In Wang et al..$^{57}$ work, the structures of PDB code 1US0 and 2FZD were simulated, in addition to a mutant 2PDK (L301M). This latter structure was replaced by 2NVD because they have similar conformations among residues of catalytic site $(\mathrm{RMSD}=0.101$, Figure S1, Supplementary Information
(SI) section), but in absence of mutations. Finally, 3DN5 structure was chosen due to different conformations of the residues on active site and the chemical similarity between the cocrystallized ligand and the inhibitors proposed here, like sulfur atoms and carboxylic acid portions.

Firstly, we performed the validation of the chosen molecular docking method by means of redocking experiments. In these assays, we implemented the molecular docking with cocrystallized ligands in their respective crystallographic enzyme structures to evaluate if the same conformation can be achieved after the simulations. After the redocking simulations, we observed that the ligands showed high conformational similarity ( RMSD $<0.5 \AA$ ), in comparison with the original position of the cocrystallized ligands (Figures 3a-3d). It was also observed that the cocrystallized ligands interact with the Tyr48, His 110 and Trp111, important residues for catalysis.

By performing redocking experiments in the 3DN5 structure, we found that ligand $53 \mathrm{~N}$ also interacts with Leu300, a residue located at the specificity pocket. ${ }^{11}$ Conformational changes were also observed in others residues from the specificity pocket (Leu301, Ser 302 and Cys303) among all structures studied herein, as reported in previous literature. ${ }^{55-57}$ In addition, the change in the specificity pocket conformation alters the opening of the binding site, which switches between open (Figure 4a) and closed (Figure $4 \mathrm{~b}$ ) depending on the ligand, contributing to distinct docking results in different crystallographic structures. ${ }^{58}$
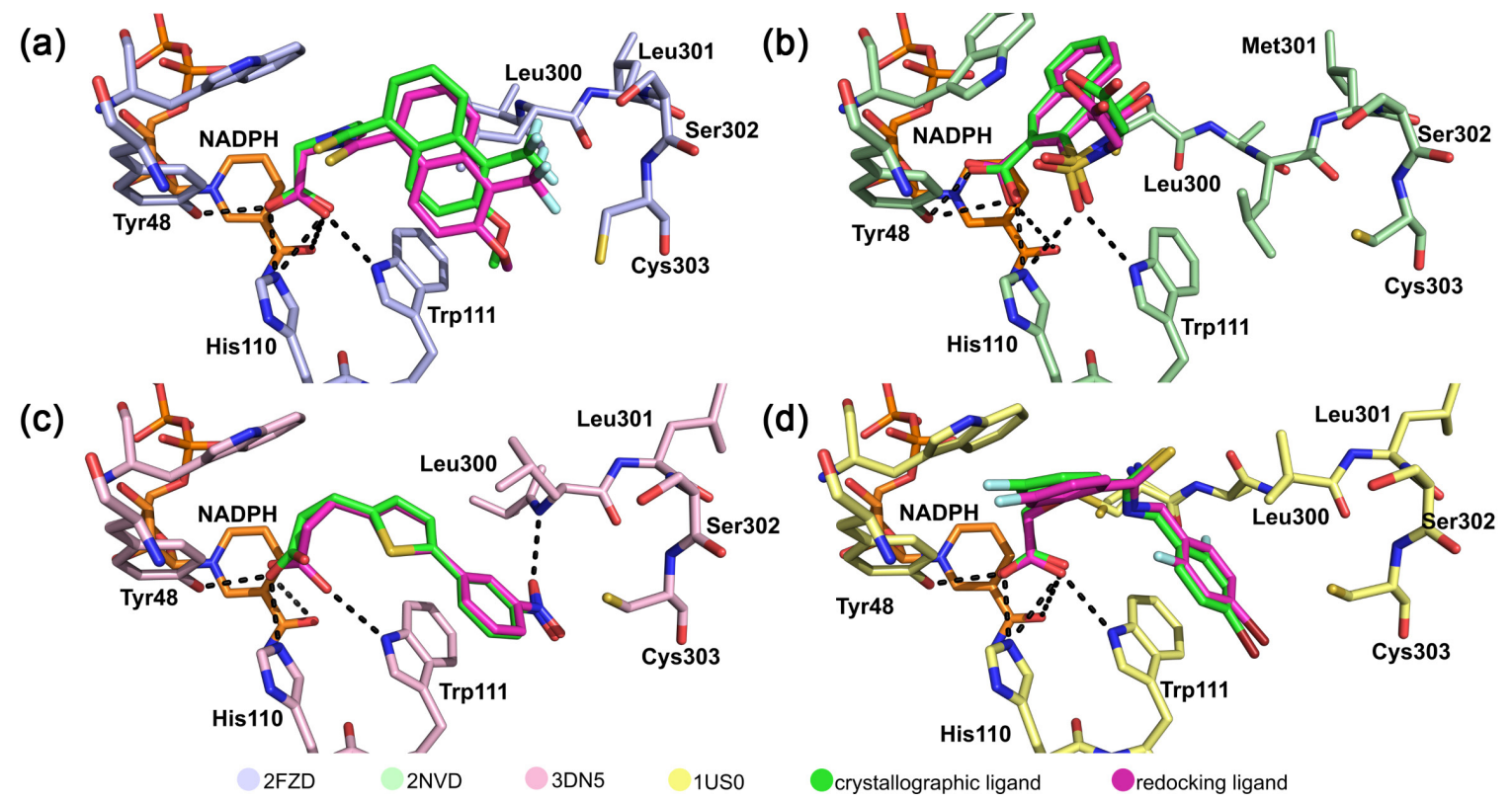

Figure 3. Redocking simulations of cocrystallized ligands (a) tolrestat (TOL), (b) 2-(carboxymethyl)-1,3,3-trioxo-naphtho[4,3-d][1,2]thiazole-4-carboxylic acid (ITB), (c) 3-[5-(3-nitrophenyl)thiophen-2-yl]propanoic (53N) and (d) IDD594 (LDT) in AR structures, where RD corresponds to the structure after redocking. 

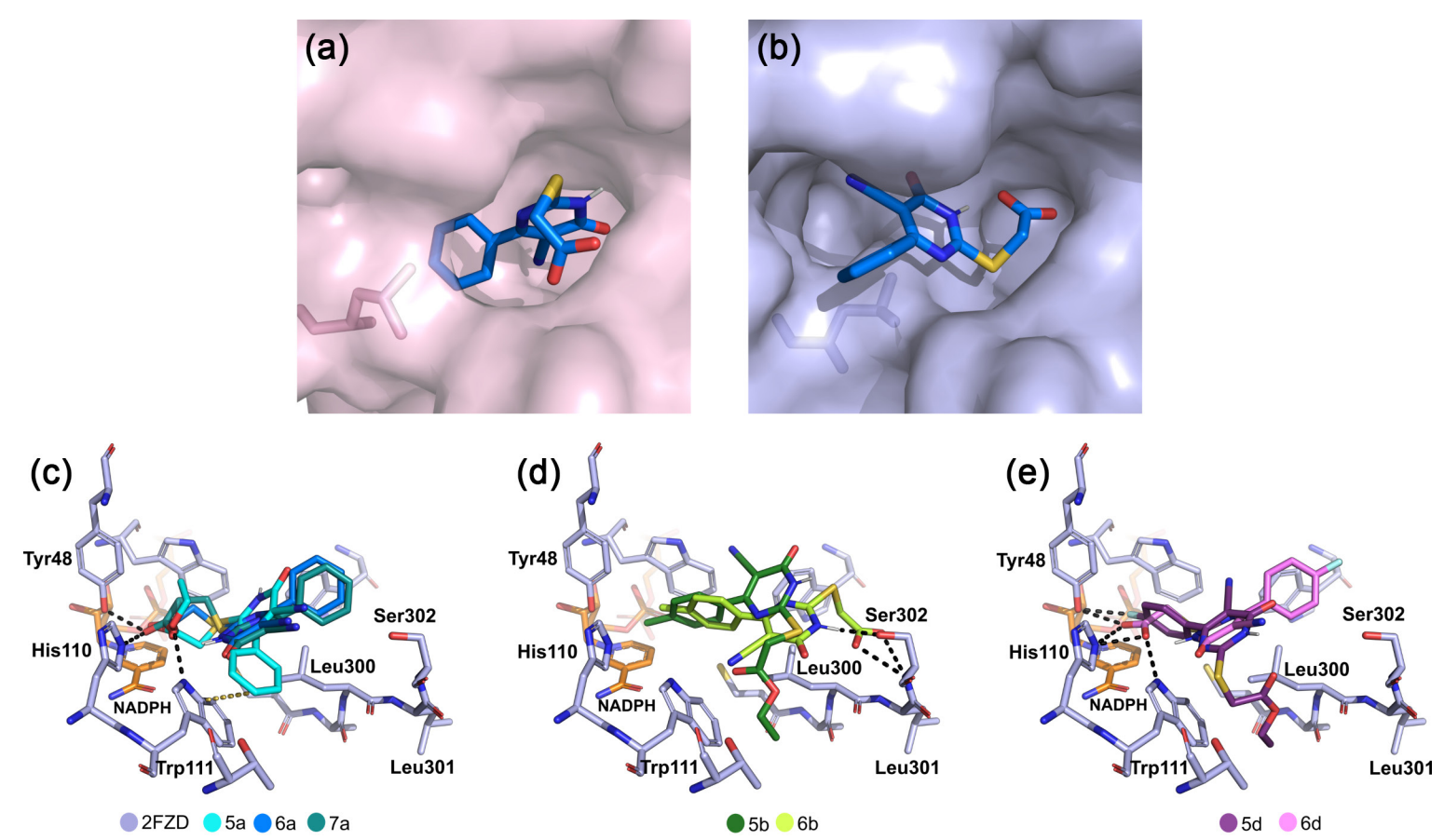

Figure 4. (a) Binding mode of $\mathbf{6 a}$ with the specificity pocket in the open conformation, the protein surface is shown in light pink; (b) binding mode with the specificity pocket in the closed conformation, the protein surface is shown in light blue. Conformation from the most populous cluster for the compounds (c) 5a, 6a, and 7a; (d) $5 \mathbf{b}$ and $6 \mathbf{b}$; (e) $5 \mathbf{d}$ and $6 \mathbf{d}$.

After the redocking studies, we began to investigate how series $\mathbf{5}, \mathbf{6}$ and $\mathbf{7}$ would interact in the available crystallographic structures. The results obtained after simulations for all ligands in each AR structure showed different binding modes varying with the structure employed, which would be expected due to conformational changes at the binding site. The structures 1US0 and 2NVD showed the fewest interactions of strong character (hydrogen bond). The structures 2FZD and 3DN5 presented more interactions at the catalytic subpocket, and the resulting conformations showed interactions with residues Tyr48, His110 and Trp111, which are the same as described in the redocking experiments. Between these two structures, 2FZD was the one with the greater number of strong interactions for most of the tested ligands.

Since the 2FZD structure showed the best binding modes for most compounds, we decided to use this enzyme as a model to further correlate the results obtained from in vitro assays (Figure 4 ). The most populous cluster was chosen for each compound (out of 200 runs). Experimental results with the canonical compounds 5a, 6a and 7a showed that ligand 5a was the most promising inhibitor, with the lowest $\mathrm{IC}_{50}$ value $(5.9 \mu \mathrm{M})$. In the docking simulations, all three ligands occupied the catalytic subpocket, interacting specifically with the residues Tyr48, His110 and Trp111. However, we noted that the ligand $\mathbf{5 a}$ displayed a different direction in accommodating its aromatic ring, thus interacting with Trp111 through $\pi$-stacking interactions
(Figure 4c). This extra interaction should be the reason for its best performance as an inhibitor. In the case of acidic derivatives $\mathbf{6 a}$ and $\mathbf{7 a}$, there were no significant conformational differences at the active site, even though $\mathbf{6 a}$ is the most active among the two compounds.

Ligands 5b and 6b (Figure 4d), and 5d and 6d (Figure 4e) showed different conformations among them. Ligands $5 \mathbf{b}$ and $\mathbf{6 b}$ both interact specifically with the specificity pocket residues. Compound $\mathbf{6 b}$ interacts with Ser302, while $\mathbf{5 b}$ does not bind via a stronger force, which explains the lowest $\mathrm{IC}_{50}$ for $\mathbf{6 b}(2.0 \mu \mathrm{M})$. On the other hand, compounds 5d and $\mathbf{6 d}$ interact mostly with the catalytic subpocket, as seen for canonical compounds. While ligand 6d interacts with Tyr48, His110 and Trp111 residues, compound 5d interacts only with Tyr48. Interestingly, this approach is mediated by the fluorine atom and not via the carbonyl group, as observed for other derivatives. Compound $\mathbf{6 d}(3.3 \mu \mathrm{M})$ is more active and this is possibly due to its multiple interactions with the AR active site.

\section{Conclusions}

Fifteen thiopyrimidinones were synthesized and obtained in yields ranging from 45 to $90 \%$ and have emerged as new aldose reductase inhibitors. These compounds were evaluated in vitro as AR inhibitors using a colorimetric method. In the first round, all synthesized compounds were screened at a fixed concentration of 50 micromolar. From 
these results, some derivatives stood out as promising drug candidates. Next, the canonical compounds $5 \mathbf{a}, \mathbf{6 a}$ and $7 \mathbf{a}$ were evaluated individually and their respective $\mathrm{IC}_{50}$ were 5.9, 8.2 and $14.5 \mu \mathrm{M}$. We then performed molecular docking simulations with these ligands in four AR crystallographic structures to assess the enzyme-inhibitor interactions. All compounds showed interactions with the AR catalytic subpocket, especially compound $\mathbf{5 a}$, which showed more interactions with the AR binding site and, consequently, lower $\mathrm{IC}_{50}$ value. In the acid derivatives $6 \mathbf{a}$ and $\mathbf{7 a}$, we could observe that the elongation of the lateral chain does not favor AR inhibition. Regarding the compounds $\mathbf{5 b}$ and $\mathbf{5 d}$, results showed that $p$-methyl substitution in the aromatic ring is not as favorable as $p$-F substitution with respect to AR inhibition, thus increasing $\mathrm{IC}_{50}$ values $(\mathbf{5 b}-8.7 \mu \mathrm{M}$ and $\mathbf{5 d}-6.4 \mu \mathrm{M})$. Compounds $\mathbf{6 b}$ and $\mathbf{6 d}$ showed the lowest $\mathrm{IC}_{50}$ values (2.0 and $3.3 \mu \mathrm{M}$, respectively), and these results indicate that even though compound 5a happens to be the most promising among the canonical compounds, serie 6 (containing a $-\mathrm{CH}_{2} \mathrm{COOH}$ moiety), especially compounds $\mathbf{6 b}$ and $\mathbf{6 d}$, were the two most promising thiopyrimidinones as AR inhibitors. Molecular docking simulations were helpful to better understand the enzyme-inhibitor interactions that could explain the differences in $\mathrm{IC}_{50}$ values among all compounds tested herein. Redocking experiments were successful and all thiopyrimidinones showed interactions in the catalytic subpocket (Tyr48, Lys77, His110, Trp111 and the cofactor NADPH). Among the canonical compounds 5a, 6a and $\mathbf{7 a}$, the compound $\mathbf{5 a}$ displays a different conformation, allowing the $\pi$-stacking interaction with Trp111. However, in an in-depth investigation about the influence of aromatic ring substitutions, the compounds $\mathbf{6 b}$ and $\mathbf{6 d}$, which showed the best $\mathrm{IC}_{50}$ values, showed more and stronger interactions than the compounds $\mathbf{5 b}$ and $\mathbf{5 d}$. Even though the thiopyrimidinones described herein displayed $\mathrm{IC}_{50}$ values at a low micromolar range, modifications on aromatic ring substituents (e.g., $-\mathrm{NO}_{2}$ groups or fused rings) will be further investigated to improve their AR inhibitory activity to the nanomolar range.

\section{Supplementary Information}

Supplementary information regarding NMR spectra and ligands and enzyme coordinates extracted from molecular docking simulations are available free of charge at http://jbcs.sbq.org.br as PDF file.

\section{Acknowledgments}

We thank Dr Maria Helena N. L. Silva-Filha for the use of spectrophotometer in AR inhibition assays. IMSL acknowledges CAPES for the graduate fellowship. LGM acknowledges CAPES-RIMA for the post-doctoral fellowship.

\section{References}

1. Ramana, K. V.; Biomol. Concepts 2011, 2, 103.

2. Singh Grewal, A.; Bhardwaj, S.; Pandita, D.; Lather, V.; Singh Sekhon, B.; Mini-Rev. Med. Chem. 2015, 16, 120.

3. Brownlee, M.; Aiello, L. P.; Cooper, M. E.; Vinik, A. I.; Plutzky, J.; Boulton, A. J. M.; Complications of Diabetes Mellitus; Elsevier Inc.: Philadelphia, 2016.

4. Cheloni, R.; Gandolfi, S. A.; Signorelli, C.; Odone, A.; BMJ Open 2019, 9, e022188.

5. Bosco, A.; Lerário, A. C.; Soriano, D.; dos Santos, R. F.; Massote, P.; Galvão, D.; Franco, A. C. H. M.; Purisch, S.; Ferreira, A. R.; Arq. Bras. Endocrinol. Metabol. 2005, 49, 217.

6. Hammes, H. P.; Bartmann, A.; Engel, L.; Wülfroth, P.; Diabetologia 1997, 40, 629.

7. Pradhan, R.; Fong, D.; March, C.; Jack, R.; Rezapour, G.; Norris, K.; Davidson, M. B.; J. Diabetes Complications 2002, 16, 377.

8. Nicholson, B. P.; Schachat, A. P.; Graefe's Arch. Clin. Exp. Ophthalmol. 2010, 248, 915.

9. Kraemer, O.; Hazemann, I.; Podjarny, A. D.; Klebe, G.; Proteins: Struct., Funct., Genet. 2004, 55, 814.

10. Ogawva, K.; Yamawaki, I.; Matsusita, Y.; Nomura, N.; Kador, P.; Kinoshita, J.; Eur. J. Med. Chem. 1993, 28, 769.

11. Eisenmann, M.; Steuber, H.; Zentgraf, M.; Altenkämper, M.; Ortmann, R.; Perruchon, J.; Klebe, G.; Schlitzer, M.; ChemMedChem 2009, 4, 809.

12. Ramirez, M. A.; Borja, N. L.; Pharmacotherapy 2008, 28, 646.

13. Jin, K. J.; Yin, H.; de Clercq, E.; Pannecouque, C.; Meng, G.; Chen, F. E.; Eur. J. Med. Chem. 2018, 145, 726.

14. Mohamed, M. S.; Youns, M. M.; Ahmed, N. M.; Eur. J. Med. Chem. 2013, 69, 591.

15. Madhu Sekhar, M.; Nagarjuna, U.; Padmavathi, V.; Padmaja, A.; Reddy, N. V.; Vijaya, T.; Eur. J. Med. Chem. 2018, 145, 1.

16. Borik, R. M.; Fawzy, N. M.; Abu-Bakr, S. M.; Aly, M. S.; Molecules 2018, 23, 1398.

17. Ahmed, N. M.; Youns, M.; Soltan, M. K.; Said, A. M.; J. Enzyme Inhib. Med. Chem. 2019, 34, 1110.

18. La Motta, C.; Sartini, S.; Mugnaini, L.; Simorini, F.; Taliani, S.; Salerno, S.; Marini, A. M.; da Settimo, F.; Lavecchia, A.; Novellino, E.; Cantore, M.; Failli, P.; Ciuffi, M.; J. Med. Chem. 2007, 50, 4917.

19. Brown, D. J.; Comprehensive Heterocyclic Chemistry; Katritzky, A. R.; Rees, C. W., eds.; Pergamon Press: Oxford, 1984, p. 57.

20. Kappe, C. O.; Eur. J. Med. Chem. 2000, 35, 1043.

21. de Andrade, A. N.; Araújo, A. V.; Barbosa, H. B. W.; Wanderley, A. G.; Malta, O. L.; dos Anjos, J. V.; J. Braz. Chem. Soc. 2017, 28,1266 . 
22. Ugi, I.; Dömling, A.; Hörl, W.; Endeavour 1994, 18, 115.

23. Abd El-Fatah, N. A.; Darweesh, A. F.; Mohamed, A. A.; Abdelhamid, I. A.; Elwahy, A. H. M.; Tetrahedron 2017, 73, 1436.

24. Martos-Calvente, R.; de la Peña O'Shea, V. A.; Campos-Martin, J. M.; Fierro, J. L. G.; J. Phys. Chem. A 2003, 107, 7490.

25. Amr, A. G. E.; Mohamed, A. M.; Mohamed, S. F.; Abdel-Hafez, N. A.; Hammam, A. E. F. G.; Bioorg. Med. Chem. 2006, 14, 5481.

26. Sondhi, S. M.; Singh, N.; Johar, M.; Kumar, A.; Bioorg. Med. Chem. 2005, 13, 6158.

27. Ram, V. J.; Arch. Pharm. (Weinheim) 1990, 323, 895.

28. Kambe, S.; Saito, K.; Kishi, H.; Sakurai, A.; Midorikawa, H.; Georg Thieme Publ. 1979, 1979, 287.

29. Khodair, A. I.; Ibrahim, E. E.; El Ashry, E. S. H.; Nucleosides Nucleotides 1997, 16, 433.

30. Fadda, A. A.; El-Latif, E. A.; Bondock, S.; Samir, A.; Synth. Commun. 2008, 38, 4352.

31. Patel, A.; Pasha, T.; Kothari, R.; J. Chem. Pharm. Res. 2015, 7, 509 .

32. Hussain, S. M.; El-Reedy, A. M.; Rezk, A. M. H.; El-Dien, K. A. S.; J. Heterocycl. Chem. 1987, 24, 1605.

33. El-Naggar, A. M.; Abou-El-Regal, M. M.; El-Metwally, S. A.; Sherbiny, F. F.; Eissa, I. H.; Mol. Diversity 2017, 21, 967.

34. Scripps Research; AutoGrid; 4.0; Molecular Graphics Laboratory, USA, 2014.

35. Scripps Research; AutoDock; 4.0; Molecular Graphics Laboratory, USA, 2014.

36. Morris, G. M.; Ruth, H.; Lindstrom, W.; Sanner, M. F.; Belew, R. K.; Goodsell, D. S.; Olson, A. J.; J. Comput. Chem. 2009, $30,2785$.

37. Goodford, P. J.; J. Med. Chem. 1985, $28,849$.

38. Oliveira, V. S.; Pimenteira, C.; da Silva-Alves, D. C. B.; Leal, L. L. L.; Neves-Filho, R. A. W.; Navarro, D. M. A. F.; Santos, G. K. N.; Dutra, K. A.; dos Anjos, J. V.; Soares, T. A.; Bioorg. Med. Chem. 2013, 21, 6996.

39. Maciel, L. G.; Oliveira, A. A.; Romão, T. P.; Leal, L. L. L.; Guido, R. V. C.; Silva-Filha, M. H. N. L.; dos Anjos, J. V.; Soares, T. A.; Bioorg. Med. Chem. 2020, 28, 115252.

40. PDB, 3DN5, https://www.rcsb.org/structure/3DN5, accessed in February 2022; PDB, 2FZD, https://www.rcsb.org/ structure/2FZD, accessed in February 2022; PDB, 2NVD, https://www.rcsb.org/structure/2NVD, accessed in February 2022; PDB, 1US0, https://www.rcsb.org/structure/1US0, accessed in February 2022.
41. Weiner, S. J.; Kollman, P. A.; Nguyen, D. T.; Case, D. A.; J. Comput. Chem. 1986, 7, 230.

42. Soares, T. A.; Goodsell, D. S.; Briggs, J. M.; Ferreira, R.; Olson, A. J.; Biopolymers 1999, 50, 319.

43. Soares, T.; Goodsell, D.; Ferreira, R.; Olson, A.; Briggs, J.; J. Mol. Recognit. 2000, 13, 146.

44. The PyMOL Molecular Graphics System, 2.4.1; Schrödinger, LLC, USA 2020.

45. Jadhav, C. K.; Nipate, A. S.; Chate, A. V.; Songire, V. D.; Patil, A. P.; Gill, C. H.; ACS Omega 2019, 4, 22313.

46. Ramiz, M. M. M.; El-Sayed, W. A.; Hagag, E.; Abdel-Rahman, A. A.-H.; J. Heterocycl. Chem. 2011, 48, 1028.

47. Chitre, T. S.; Bothara, K. G.; Chem. Sin. 2011, 2, 187.

48. Xavier, A. L.; Simas, A. M.; Falcão, E. P. D. S.; dos Anjos, J. V.; Tetrahedron Lett. 2013, 54, 3462.

49. Allegretti, P.; Schiavoni, M. M.; Cortizo, M.; Castro, E.; Furlong, J.; Int. J. Mol. Sci. 2004, 5, 294.

50. Pearson, R. G.; J. Am. Chem. Soc. 1963, 85, 3533.

51. Haynes W. M. In CRC Handbook of Chemistry and Physics, 97 $7^{\text {th }}$ ed.; CRC Press: New York, 2016.

52. Deruiter, J.; Brubaker, A. N.; Millen, J.; Riley, T. N.; J. Med. Chem. 1986, 4, 627.

53. Howard, E. I.; Sanishvili, R.; Cachau, R. E.; Mitschler, A.; Chevrier, B.; Barth, P.; Lamour, V.; van Zandt, M.; Sibley, E.; Bon, C.; Moras, D.; Schneider, T. R.; Joachimiak, A.; Podjarny, A.; Proteins: Struct., Funct., Genet. 2004, 55, 792.

54. Steuber, H.; Heine, A.; Podjarny, A.; Klebe, G.; J. Mol. Biol. 2008, 379, 991

55. Steuber, H.; Zentgraf, M.; Gerlach, C.; Sotriffer, C. A.; Heine, A.; Klebe, G.; J. Mol. Biol. 2006, 363, 174.

56. Sotriffer, C. A.; Krämer, O.; Klebe, G.; Proteins: Struct., Funct., Genet. 2004, 56, 52.

57. Wang, L.; Gu, Q.; Zheng, X.; Ye, J.; Liu, Z.; Li, J.; Hu, X.; Hagler, A.; Xu, J.; J. Chem. Inf. Model. 2013, 53, 2409.

58. Rechlin, C.; Scheer, F.; Terwesten, F.; Wulsdorf, T.; Pol, E.; Fridh, V.; Toth, P.; Diederich, W. E.; Heine, A.; Klebe, G.; ACS Chem. Biol. 2017, 12, 1397.

Submitted: September 1, 2021 Published online: February 4, 2022 